\title{
KECERDASAN VERBAL LINGUISTIK PADA PENERAPAN DUA BAHASA DALAM PEMBELAJARAN DI SEKOLAH DASAR NAHDLATUL ULAMA KRATON KENCONG JEMBER
}

\author{
Mukni'ah \\ IAIN Jember \\ mukniah@gmail.com
}

\begin{abstract}
The bilingual program is a language intelligence improvement program having a focus to use two languages in the teaching and learning activities at school. This article aims to describe the listening, speaking, reading, and writing skills of students in the application of two languages in elementary schools learning. This study was carried out at the Nahdlatul Ulama Elementary School in Kraton, Kencong Jember. The approach used in this study is qualitative with the type of case study research. Purposive method was used in subject selection. The data were collected through observation, interviews, and documentation. The data was analyzed by using the interactive analysis of the Miles and Huberman models which consisted of data condensation, data presentation, and drawing conclusion. The validity of the data was checked through triangulation of sources and techniques. The results of this study indicate that: (1) The students' listening ability was done interactively in grades one and two which can be categorized as excellence: (2) The ability to speak interactively of students in grade one is carried out by role playing activities and in grade two is carried out by discussing activities about attitudes towards friends and presenting the results of the discussion in front of the class. (3) The reading ability of students is implemented in learning through reading aloud. (4) Students' writing skills are carried out through reviewing activities or summarizing using imaginative strategies.
\end{abstract}

Keywords: Verbal Linguistics, Bilingual, Elementary School Learning.

\section{PENDAHULUAN}

Kecerdasan memegang peranan penting dalam mencapai keberhasilan. Perkembangan dua bahasa pada anak-anak sudah menjadi topik penelitian yang sangat populer. yang bisa dibuktikan dengan banyaknya publikasi hasil penelitian dalam jurnal-jurnal ilmiah. Salah satu pembatasan topik tentang bilingual pada anak-anak adalah tentang dua proses peningkatan kemampuan berbahasa yaitu: pemerolehan bahasa (language acquistion). ${ }^{1}$

Setiap pembelajaran peserta didik memiliki kecerdasan masing-masing yang harus dikembangkan. Salah satu kecerdasan yang dimiliki oleh peserta didik adalah kecerdasan verbal linguistik. Kecerdasan Verbal linguistik merupakan kecerdasan dalam menggunakan bahasa

\footnotetext{
${ }^{1}$ Lut Putu Artini \& Putu Kerti Nitiasih. 2014. Bilingualisme dan Pendidikan Bilingual, (Yogyakarta: Graha IImu). 97.
} 
dan kata-kata baik secara lisan maupun tulisan, ${ }^{2}$ Kecerdasan verbal linguistik adalah kecerdasan dalam mengelola kata, dan merupakan kecerdasan paling universal diantara ketujuh kecerdasan dalam teori kecerdasan ganda. Kecerdasan verbal linguistik adalah kecerdasan dalam mengelola kata atau kemampuan menggunakan kata secara efektif baik secara lisan maupun tulisan. Orang yang cerdas dalam bidang ini dapat berargumentasi, meyakinkan orang, menghibur atau mengajar dengan efektif lewat kata-kata yang diucapkan. ${ }^{3}$

Hal ini sesuai dengan firman Allah dalam al-quran surah al-Isra ayat 70:

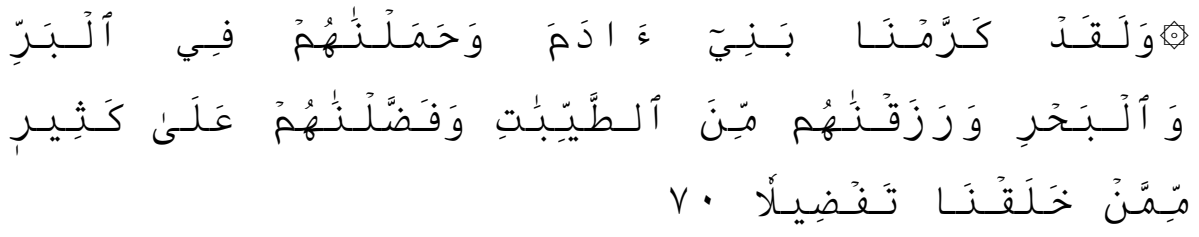

yang artinya : Dan sesungguhnya telah kami muliakan anak-anak adam, kami angkat mereka di daratan dan di lautan, kami beri mereka rizki dari yang baik-baik dan kami lebihkan mereka dengan mereka dengan kelebihan yang sempurna atas kebanyakan makhluk yang telah kami ciptakan. (Q. S. Al-Isra 70). ${ }^{4}$

Ayat tersebut dapat difahami bahwa Allah telah mengkaruniakan berbagai kelebihan yang sempurna kepada seluruh umat manusia ciptaannya. Salah satunya adalah akal yang menjadi pembeda dengan mahluk ciptaan lain yang dapat digunakan berpikir demi kelangsungan hidupnya dan kehidupan orang sekitarnya. Kemampuan akal ini yang nantinya akan direpresentasikan pada proses kegiatan belajar dan mengajar dalam domain pendidikan.

Pendidikan merupakan hal yang sangat penting bagi setiap negara jika negara tersebut ingin maju. Tujuan Pendidikan sendiri adalah menciptakan generasi yang tidak hanya pintar dalam pengetahuan, tetapi generasi yang memiliki sikap spiritual, berakhlak mulia dan mempunyai keterampilan, ${ }^{5}$ Sebagai negara yang sedang melaksanakan pembangunan dalam segala bidang, salah satunya bidang pendidikan, Pendidikan Nasional Indonesia melaksanakan sebuah sistem dalam rangka mencerdsakan kehidupan bangsa sebagai salah satu cita-cita yang tercantum dalam pembukaan UUDN RI tahun 1945.

\footnotetext{
${ }^{2}$ Hanifah. 2014. Pemanfaatan media pop-up book berbasis tematik untuk meningkatkan kecerdasan verballinguistik anak usia 4-5 tahun (studi eksperimen di TK negeri pembina bulu temanggung). Belia: Early Childhood Education Papers. 3 (2). 46

3 Deni Kurniawan. 2014. Pembelajaran Terpadu Tematik (Teori, Praktik, dan Penilaian. (Bandung : Alfabeta, 2014). 4.

${ }^{4}$ al-Quran, Microsoft Word, 2010. 17:70.

${ }^{5}$ Utama, M.M.A. 2018. Pengembangan Penilaian Authentik Bagi Guru MI .Indonesian Journal Of Islamic Teaching. $1(1) .2$
} 
Pendidikan merupakan proses budaya untuk meningkatkan harkat dan martabat manusia yang diperoleh melalui proses yang panjang dan berlangsung sepanjang kehidupan, dengan pendidikan Siswa menerapkan apa yang dipelajari di sekolah ke lingkungan tempat mereka tinggal. ${ }^{6}$ Sebagaimana dirumuskan dalam tujuan pendidikan nasional Undang-Undang Sistem Pendidikan Nasional Nomor 20 Tahun 2003 Bab II, tentang dasar, fungsi dan tujuan pendidikan pasal 3 sebagai berikut:

Pendidikan nasional berfungsi mengembangkan kemampuan dan bentuk watak serta peradaban bangsa yang bermartabat dalam rangka mencerdaskan kehidupan bangsa, bertujuan untuk berkembangnya potensi peserta didik agar menjadi manusia yang beriman dan bertakwa kepada Tuhan Yang Maha Esa, berakhlak mulia, sehat, berilmu, cakap, kreatif, mandiri, dan menjadi warga negara yang demokratis serta bertanggung jawab. ${ }^{7}$

Setiap individu memperoleh bahasa pertamanya dengan cara yang alamiah, melalui interaksi dengan orang yang paling dekat dengan kehidupannya misalkan, Ibu, Ayah, saudara dan keluarga besar. Selain itu, dalam interaksinya dengan orang lain, atau saat anak-anak belajar di lembaga formal (sekolah), bahasa kedua hadir dalam kehidupan mereka. ${ }^{8}$

Kemampuan belajar peserta didik, serta kemampuan guru mengetahui dan memanfaatkan kecerdasan verbal linguistik peserta didik akan tumbuh mencapai tujuan pembelajaran, sehingga tercapainya tujuan pembelajaran yang diinginkan sesuai dengan indikator pencapain.

Program bilingual didefinisikan sebagai kemampuan menggunakan dua bahasa, salah satu diantranya adalah bahasa asing dianggap memiliki reputasi tinggi dan merupakan pergaulan dunia yaitu Bahasa Inggris. ${ }^{9}$

Salah satu sekolah tingkat dasar di Kabupaten Jember yang menerapkan pendidikan bilingual yaitu Sekolah Dasar Nahdatul Ulama Kraton Kencong Jember, program bilingual di Sekolah Dasar Nahdatul Ulama Kraton Kencong Jember ini masih berjalan dua tahun program ini di terapkan pada kelas bawah, bahasa yang di gunakan yaitu Bahasa Jawa Krama Inggil dan Bahasa Inggris, namun penggunaan buku masih sama dengan kelas reguler menggunakan buku tematik yang berbahasa Indonesia karena buku yang berbahasa Jawa dan bahasa Inggris tidak

\footnotetext{
${ }^{6}$ Utama, M.M.A. 2020. Student Motivation in Thematic Learning at Elementary Schools.Southeast Asean Journal Of Islamic Education. 3 (1). 1

7 Undang-Undang. 2018. SISDIKNAS (Sistem Pendidikan Nasional) \& PP No 32 Tahun 2013 Tentang Perubahan PP No. 19 Tahun 2015 Tentang Standar Pendidikan Nasional (Jakarta : Permata Press, 2018). 6.

${ }^{8}$ Lut Putu Artini \& Putu Kerti Nitiasih. 2014. Bilingualisme dan Pendidikan Bilingual, (Yogyakarta: Graha IImu, 2014). 3.

${ }^{9}$ Lut Putu Artini \& Putu Kerti Nitiasih. 2014. Bilingualisme dan Pendidikan Bilingual, (Yogyakarta: Graha Ilmu) V.
} 
ada. Karena program bilingual ini di terapkan di kelas bawah dalam penerapan penggunaan bahasa Inggris guru hanya menerapkan pada kata-kata yang mudah di ingat seperti open book, close book, dan pada awal pembukaan pelajaran, penutupan dalam pelajaran. Penggunaan Bahasa Inggris lebih di tekankan ketika pada kelas atas, di kelas bawah peserta didik lebih difokuskan dalam penerapan Bahasa Jawa Krama Inggil. ${ }^{10}$

Bilingual pada prinsipnya yaitu program penggunaan bahasa pengantar Bahasa Jawa Krama Inggil dan Bahasa Inggris dalam semua pelajaran, sebagai program yang baru di terapkan dalam pembelajaran tentunya memiliki banyak kendala. Penerapan program kelas dua bahasa atau bilingual masih jarang diterapkan pada tingkat dasar khususnya Sekolah Dasar Nahdatul Ulama Kraton Kencong Jember sangat mendukung anak untuk mengembangkan kemampuan berbahasanya serta melatih kecerdasan anak untuk memahami bahasa lingkungan yaitu bahasa Jawa Krama Inggil dan Bahasa Inggris dengan baik.

\section{KAJIAN TEORI}

\section{Kecerdasan Linguistik}

Kecerdasan pada mulanya diartikan dalam bahasa sehari-hari sebagai kemampuan untuk menyelsaikan persoalan-persoalan praktis. ${ }^{11}$ kecerdasan hanya muncul dalam tindakan atas dasar pemahaman yang mendalam, sedangkan trial and error adalah salah satu bentuk dari training (latihan). ${ }^{12}$ Howard Gardner mengatakan bahwa setiap orang memiliki bermacammacam kecerdasan, tetapi dengan kadar pengembangan yang berbeda. ${ }^{13}$

Kecerdasan linguistik adalah kemampuan menggunakan kata secara efektif, baik secara lisan (pendongeng, orator, politisi) maupun tertulis (sastrawan, penulis, drama, editor, wartawan). ${ }^{14}$ Kecerdasan ini meliputi kemampuan memanipulasi tata bahasa atau struktur bahasa, fenologi atau bunyi bahasa. Menurut Kenzeie yang dikutip Muhammad Yaumi, kecerdasan linguistik disebut juga kecerdasan verbal karena mencakup kemampuan untuk mengekspresikan diri secara lisan dan tertulis serta kemampuan untuk menguasai bahasa asing. ${ }^{15}$

\footnotetext{
10 Observasi, Jember , 29 Januari 2019

${ }^{11}$ Suarca. 2016. Kecerdasan Majemuk Pada Anak. Jurnal Sari Pedriatri, 7 (2), 87

12 Yaumi . 2015. Desain Strategi Pembelajaran untuk Mengembangkan Kecerdasan Verbal-Linguistik Peserta Didik. Auladuna: Jurnal Pendidikan Dasar Islam, 2 (2), 186

13 Chatib dan Alamsyah said.2012. Sekolahnya Anak-anak Juara: Berbasis Kecerdasan Jamak dan Keadilan (Bandung: Kaifa). 78-79.

${ }^{14}$ Muhammad Yaumi. 2018. Pembelajaran berbasis Multiple Intellegences (Jakarta: PT Dian Rakyat) . 40-41.

15 Muhammad Yuaumi dan Nurdin Ibrahim. 2013. Pembelajaran Berbasis Kecerdasan Jamak (Multiple Intellegence) Mengidentifikasi dan Mengembangkan Multitalenta Anak (Jakarta: Prenamedia Group). 13.
} 
Kecerdasan linguistik adalah kemampuan menyusun pikiran dengan jelas dan mampu menggunakan kemampuan ini secara kompeten melalui kata-kata untuk untuk mengungkapkan pikiran, pikiran-pikiran dalam bicara, membaca, dan menulis, biasanya kecerdasan ini dimiliki oleh para orator, negosiator, pengacara, atau para pemimpin negara dunia. ${ }^{16}$ Kecerdasan linguistik adalah kemampuan dalam menyusun kata-kata dengan jelas untuk mengungkapkan melalui berbicara, membaca, dan menulis

Beberapa strategi mengajar yang melibatkan kecerdasan linguistik diantaranya yaitu ceramah, diskusi, tanya jawab, wawancara, presentasi, pelaporan oral, reporter, bercerita, dongeng, debat, membaca nyaring, puisi, tebak kata, aksara bermakna, pantun, menulis imajinatif, menulis informasi, menulis cerpen, menulis novel, menulis cerita dari komik, menulis laporan, menulis personal, kosakata, teka-teki silang, pidato, acak kata, dan menyusun skenario.

Menumbuhkan kemauan membaca pada anak dapat melalui bercerita melaui media buku, siswa tidak akan lupa sebuah materi apabila dismpaikan dengan cara siswa diminta untuk bercerita karena siswa cenderung terus mengulang-ulang cerita tersebut, bagi Storyteller pemula, kecemasan dapat berkurang jika siswa mampu menyampaikan cerita ke kelompok kecil yang terdiri dari empat atau lima siswa, tidak langsung ke kelas besar. ${ }^{17}$

Strategi membaca nyaring terkait erat dengan kecerdasan linguistik, karena ketika peserta didik membaca suatu teks bacaan mereka mengingat isinya, dan menarik kesimpulan dari apa yang dibaca oleh peserta didik. Membaca nyaring adalah aktivitas membaca dengan suara nyaring untuk memahami dan mengembangkan keterampilan mendengar aktif, untuk menganalisis suatu temuan dalam bacaan, semisal kosakata baru yang tidak dipahami atau redaksional kalimat yang menjelaskan mengenai suatu peristiwa. ${ }^{18}$

Kecerdasan lingusitik sangat mempengaruhi kemampuan seseorang terhadap bahasa dan kosakata. Belajar menggunakan permainan kosakata memberikan gairah belajar pada kelompok siswa yang dominan linguistik, kekayaan kosakata seseorang secara umum dianggap sebagai gambaran in telegensia seseorang. ${ }^{19}$

\footnotetext{
${ }^{16}$ Munif Chatib. 2012. Orang Tuanya Manusia Melejitkan Potensi dan Kecerdasan dengan Menghargai Fitrah Setiap Anak (Bandung: Kaifa). 88.

${ }^{17}$ Alamsyah Said dan Andi Budimanjaya. 2016. 95 Strategi Mengajar Multiple Intelligences (Jakarta: Kencana), . 55.

18 Ibid., 63.

${ }^{19}$ Alamsyah Said dan Andi Budimanjaya. 2016. 95 Strategi Mengajar Multiple Intelligences (Jakarta: Kencana), . 91.
} 
Seseorang anak yang memiliki kecerdasan verbal linguistik yang tinggi anak tersebut akan mampu menceritakan cerita dan adegan lelucon, kemampuan menulisnya juga lebih baik dari rata-rata anak yang lain yang memiliki usia yang sama, memiliki ingatan yang kuat tentang nama-nama seseorang, tempat tinggal, dan informasi lain lebih baik dari pada anak umumnya, menggemari terhadap permainan kata, gemar membaca buku, menghargai sajak, dan permainan kata-kata, suka mendengar cerita tanpa melihat buku, mengkomunikasikan, pikiran perasaan, dan ide-ide dengan baik, mendengarkan dan merespon, bunyi-bunyi, irama, warna, berbagai kata-kata.

Berdasarkan dari beberapa definisi diatas dapat disimpulkan bahwa kecerdasan verbal linguistik adalah kemampuan seseorang dalam menggunakan bahasa lisan maupun tulisan, dan suka membaca, menulis, dan berbicara, dan kebanyakan mereka menggunakan kata-kata untuk membujuk, mengajak, membantah, menghibur, atau mengajari orang lain.

\section{Aspek-Aspek Kecerdasan Linguistik}

Kecerdasan verbal linguistik meliputi empat aspek yaitu sebagai berikut:

1. Mendengar

Bagi orang-orang yang bisa mendengar, suara manusia memberikan pengalaman pertama pada bahasa. ${ }^{20}$ Mendengar adalah keterampilan memahami bahasa lisan yang bersifat reseptif. Dengan demikian, mendengarkan di sini berarti bukan sekedar mendengarkan bunyi-bunyi bahasa melainkan sekaligus memahaminya. Dalam bahasa pertama (bahasa ibu), kita memperoleh keterampilan mendengarkan melalui proses yang tidak kita sadari sehingga kita pun tidak menyadari begitu kompleksnya proses pemerolehan keterampilan mendengarkan tersebut.

Ada dua jenis situasi dalam mendengarkan, yaitu situasi mendengarkan secara interaktif dan situasi mendengarkan secara noninteraktif. Mendengarkan secara interaktif terjadi dalam percakapan tatap muka dan percakapan ditelepon atau sejenis itu. Dalam mendengarkan jenis ini kita secara bergantian melakukan aktivitas mendengarkan dan berbicara, oleh karena itu kita memiliki kesempatan untuk bertanya, guna untuk memperoleh penjelasan, meminta lawan bicara mengulang apa yang diucapkan atau meminta berbicara agak lebih lambat. Kemudian contoh-contoh mendengarkan nointeraktif, yaitu mendengarkan radio, TV, film, khotbah, atau mendengarkan dalam acara-acara seremonial. Dalam mendengarkan non interaktif tersebut kita tidak dapat meminta penjelasan dari

\footnotetext{
${ }^{20}$ May Lwin. 2008. Cara Mengembangkan Berbagai Komponen Kecerdasan (Jakarta: PT. Indeks). 10.
} 
pembicara, tidak bisa minta mengulangi apa yang diucapkan, dan tidak bisa meminta berbicara diperlambat. ${ }^{21}$

Mendengarkan sesungguhnya juga merupakan proses intelektual dan emosional. Untuk dapat memberikan respon yang memadai dari apa yang didengarkan maka pendengar harus mendengar dengan penuh perhatian dan melibatkan pikiran untuk mencerna dan mengkaji terhadap apa yang didengarkan. Tujuan mendengarkan antara lain adalah mengumpulkan informasi dari apa yang didengarkan.

Dalam berinteraksi dengan seseorang apakah dengan guru atau teman di sekolah, perlu mengetahui cara mendengarkan yang baik seperti: 1) Memelihara perhatian penuh dan terpusat terhadap apa yang didengar. 2) Mendengar segala sesuatu yang dikatakan 3) Memahami perasaan pembicara terkait dengan apa yang disampaikan. Pemenuhan terhadap ketiga persyaratan diatas, menjadikan pendengar mampu memberikan respon sesuai dengan apa yang diharapkan orang lain. Jadi menjadi pendengar aktif mempersyaratkan seseorang tidak hanya memusatkan perhatian terhadap pesan-pesan yang disampaikan orang lain tetapi pendengar berusaha menjadi satu dengan seseorang yang menyampaikan pesan yang dalam bahasa komunikasi disebut dengan komunikator. ${ }^{22}$

2. Berbicara

Kemampuan berbicara dapat dikembangkan melalui belajar dan berkomunikasi dengan orang lain. Berbicara yang efektif tidak hanya melibatkan kata-kata yang digunakan nada suara, mimik wajah, sikap dan bahasa tubuh. Ada tiga jenis situasi berbicara, yaitu interaktif, semi interaktif, dan non interaktif.

Berbicara interaktif percakapan secara tatap muka dan berbicara lewat telepon yang memungkinkan adanya pergantian antara berbicara dan mendengarkan, dan memungkinkan adanya kita untuk meminta klarifikasi, pengulangan atau kita dapat meminta lawan bicara memperlambat tempo bicara dari lawan bicara.

Berbicara semiinteraktif, misalnya berpidato di hadapan umum secara langsung. Dalam situasi ini audiens memang tidak dapat melakukan interupsi terhadap pembicaraan, namun pembicara dapat melihat reaksi pendengar dari reaksi wajah dan bahasa tubuh mereka. Beberapa situasi berbicara dapat dikatakan betul-betul bersifat noninteraktif, misalnya berpidato melalui radio atau televisi. ${ }^{23}$

\footnotetext{
${ }^{21}$ Yeti Mulyati. Dkk. 2009. Keterampilan Berbahasa Indonesia SD .(Jakarta: Universitas Terbuka). 1-10.

22 Gede Sedana Yasa. 2014. Bimbingan Belajar. (Yogyakarta: Graha Ilmu). 9-10.

${ }^{23}$ Yeti Mulyati. Dkk.2009. Keterampilan Berbahasa Indonesia SD (Jakarta: Universitas Terbuka). 1-11.
} 


\section{Membaca}

Membaca adalah keterampilan reseptif bahasa tulis. Keterampilan membaca dapat dikembangkan secara tersendiri, terpisah dari keterampilan mendengarkan dan berbicara. Tetapi, pada masyarakat yang memiliki tradisi literasi yang telah berkembang, sering kali keterampilan membaca dikembangkan secara terintegrasi dengan keterampilan menyimak dan berbicara. ${ }^{24}$ Membaca melibatkan belajar memahami dan menggunakan bahasa khususnya bentuk bahasa tulis. Berbicara sering sering merupakan proses bicara yang alami, sementara membaca memerlukan usaha dan pembelajaran tertentu.

Agar kegiatan membaca lebih efisien, maka pembaca perlu mengetahui cara-cara membaca yang mengutamakan kecepatan dengan tidak mengabaikan pemahamannya. Biasanya kecepatan membaca itu dikaitkan dengan tujuan membaca, keperluan dan bahan bacaan..$^{25}$

Strategi membaca nyaring terkait erat dengan kecerdasan linguistik, karena ketika peserta didik membaca suatu teks bacaan mereka mengingat isinya, dan menarik kesimpulan dari apa yang dibaca oleh peserta didik. Membaca nyaring adalah adalah aktivitas membaca dengan suara nyaring untuk memahami dan mengembangkan keterampilan mendengar aktif, untuk menganalisis suatu temuan dalam bacaan, semisal kosakata baru yang tidak dipahami atau redaksional kalimat yang menjelaskan mengenai suatu peristiwa. ${ }^{26}$

4. Menulis

Menulis adalah keterampilan produktif menggunakan tulisan. Menulis dapat dikatakan suatu keterampilan berbahasa yang paling rumit di antara jenis-jenis keterampilan berbahasa lainnya. Karena menulis bukanlah sekedar menyalin kata-kata dan kalimat-kalimat, melainkan juga mengembangkan dan menuangkan pikiran-pikiran dalam suatu struktur tulisan yang teratur. ${ }^{27}$

Kegiatan menulis tidak dapat dipisahkan dari kegiatan bahasa lainnya. Menulis didorong oleh kegiatan berbicara, mendengar dan membaca. Memasukkan kegiatan seni

\footnotetext{
${ }^{24}$ Yeti Mulyati. Dkk. 2009. Keterampilan Berbahasa Indonesia SD (Jakarta: Universitas Terbuka). 1-12.

${ }^{25}$ Gede Sedana Yasa. 2014. Bimbingan Belajar (Yogyakarta: Graha IImu). 12.

${ }^{26}$ Alamsyah Said dan Andi Budimanjaya. 2016. 95 Strategi Mengajar Multiple Intellegensi (Jakarta: Kencana). 33.

${ }^{27}$ Yeti Mulyati. Dkk. 2009. Keterampilan Berbahasa Indonesia SD (Jakarta: Universitas Terbuka). 1.13.
} 
bahasa dalam semua area muatan dapat membantu siswa dalam berkomunikasi lebih efektif dan belajar secara menyeluruh. Peserta didik dalam kegiatan menulis dapat mengembangkan perasaan dan merasakan kegiatan menulis sebagai tindakan yang relevan yang terjadi di antara diri sendiri, orang lain dan masyarakat. Menulis dapat menyebabkan manusia untuk berkomunikasi dengan lainnya yang belum pernah bertemu. Kemampuan berpikir melalui kata-kata manusia dapat menganalisis, menyelesaikan masalah, merencanakan ke depan dan menciptakan sesuatu. ${ }^{28}$

Dari definisi-definisi diatas dapat disimpulkan bahawa kecerdasan verbal linguistik mencakup empat aspek yang saling keterkaitan, berhubungan, yaitu kemampuan dalam mendengar, berbicara, membaca, dan menulis.

\section{Dua Bahasa (Bilingualisme)}

Bilingual adalah sistem pendidikan yang menggunakan dua bahasa. Bahasa yang pertama adalah bahasa Ingris dan bahasa kedua adalah bahasa yang biasa dipakai di daerah atau negara tersebut. $^{29}$

Pendidikan bilingual adalah instruksi dalam dua bahasa dan penggunaan dua bahasa sebagai media pengantar untuk setiap bagian atau semua, dari kurikulum sekolah. Definisi ini penting, karena dalam program pendidikan ini tidak melibatkan anak-anak yang sudah bilingual (mereka umumnya belum memilki penguasaan bahasa kedua atau bahasa asing yang baik). Bahasa yang digunakan secara dominan adalah bahasa asing atau bahasa kedua tanpa mempertimbangkan tingkat latar belakang bahasa mereka. Dengan kata lain, bahasa kedua atau bahasa asing menjadi bahasa dominan di dalam kelas sampai siswa mencapai tingkat kemampuan yang baik dalam bahasa baru ini. ${ }^{30}$

Pendidikan bilingual adalah pendidikan yang menggunakan dua bahasa, bahasa pertama adalah bahasa yang digunakan sehari-hari dan bahasa kedua adalah bahasa asing, dimana peserta didik mencapai kemahiran dalam penerapan bahasa barunya, tetapi bahasa pertama tidak dihilangkan jadi tetap diterapkan dalam waktu-waktu tertentu.

\section{METODE PENELITIAN}

\footnotetext{
${ }^{28}$ May Lwin. 2008. Cara Mengembangkan Berbagai Komponen Kecerdasan. (Jakarta: PT. Indeks). 10.

${ }^{29}$ Gunarsa Singgih D. 2006. Dari Anak Sampai Usia Lanjut : Bunga Rampai Psikologi Perkembangan (Jakarta: Gunung Mulia). 90.

${ }^{30}$ Luh Putu Artini \& Putu Kerti Nitiasih. 2014. Bilingualisme dan Pendidikan Bilingual (Yogyakarta: Graha Ilmu). 100.
} 
Pendekatan atau metode yang digunakan dalam penelitian ini adalah pendekatan kualitatif, ${ }^{31}$ dengan jenis penelitian studi kasus, ${ }^{32}$ dan penentuan subyek penelitian menggunakan teknik purposive. Teknik pengumpulan data menggunakan observasi, wawancara, dan dokumentasi. Analisis data yang digunakan dalam penelitian ini model interaktif Miles dan Huberman yang terdiri dari kondensasi data, penyajian data, dan penarikan kesimpulan. Keabsahan data diuji dengan menggunakan triangulasi sumber dan teknik. ${ }^{33}$

\section{PEMBAHASAN}

Kemampuan untuk menggunakan bahasa baik secara lisan maupun tulisan dengan tepat akurat dan pas. Maksud kecerdsan verbal linguistik dalam artikel ini lebih di fokuskan pada kemampuan mendengar, kemampuan berbicara, kemampuan membaca dan kemampuan menulis, sebagai upaya mengembangkan kecerdasan siswa dalam pembelajaran di Sekolah Dasar Nahdlatul Ulama Kraton Kencong Jember.

Bilingual adalah dapat melafalkan bahasa kedua seperti melafalkan bahasa asli. "Bilingualisme diartikan sebagai kefasihan untuk berbicara dalam dua bahasa dan kedua bahasa yang dikuasai diterapkan atau digunakan.

Pendidikan bilingual yang diterapkan oleh Sekolah Dasar Nahdlatul Ulama Kraton Kencong Jember berjalan selama dua tahun, penerapan dua bahasa sudah berjalan baik, sekolah menerapkan Bahasa Jawa Krama Inggil dan Bahasa Ingris. Namun dalam penerapan awal di kelas bawah ini dominan menggunakan bahasa Jawa Krama Inggil Bahasa Inggris digunakan hanya pada kata - kata yang sederhana yang mudah untuk di lafalkan dan hafal oleh peserta didik. Penerapan bilingual diterapkan pada pembelajaran tematik karena dalam pembelajaran tematik mempelajari kehidupan yang ada di lingkungan sekitar, jadi mempermudah dalam mengaplikasikan bahasa.

Kemampuan mendengar peserta didik sebagai penerapan dua bahasa dalam pembelajaran melalui aktivitas peserta didik ketika pembelajaran tematik mendengarkan cerita dongeng fabel dari guru.

a. Interaktif

\footnotetext{
${ }^{31}$ Lexy J. Moleong. 2011. Metodologi Penelitian Kualitatif Edisi Revisi. (Bandung: Remaja). 6.

32 Durri Andriani dkk. 2011. Metode Penelitian .(Jakarta: Universitas Terbuka). 38.

33 Metthew B. Miles, etc. 2014. Qualitative Data Analysis A Methods Sourcebook. (America: Arizona State University). 12.
} 
Peserta didik dalam kemampuan mendengar sudah melaksanakan mendengar secara interaktif di kelas satu peserta didik mengikuti pelajaran dengan baik dengan melaksakan pembelajaran menjelaskan perbedaan panjang pendek lagu bertujuan untuk mengetahui kemampuan mendengar dan ketelitian peserta didik, di kelas dua mereka mendengarkan cerita dongeng dari guru kemudian merangkum pesan, ide, gagasan dalam dongeng kemudian menceritakan kembali dengan bahasa mereka sendiri.

b. Non interaktif

Peserta didik dalam kemampuan mendengar noninteraktif belum melakukan mendengar secara noninteraktif karena dalam pembelajaran di kelas bawah peserta didik belum mampu untuk melakukan mendengar secara noninteraktif karena mendengar noninteraktif biasa di terapkan di kelas atas.

Kemampuan berbicara peserta didik sebagai penerapan dua bahasa dalam pembelajaran dilaksanakan melalui aktivitas peserta didik ketika kegiatan diskusi.

a. Interaktif

Peserta didik dalam kemampuan berbicara sudah melaksanakan berbicara secara interaktif yaitu peserta didik mengikuti pelajaran dengan baik di kelas satu peserta didik melakukan aktivitas bermain peran dalam aktivitas ini semua peserta didik dituntut untuk berbicara. Di kelas dua peserta didik melakukan kegiatan diskusi tentang sikap terhadap teman kemudian peserta didik mempresentasikan hasil diskusi di depan kelas.

b. Non iteraktif

Peserta didik dalam kemampuan mendengar noninteraktif belum melakukan mendengar secara noninteraktif karena dalam pembelajaran di kelas bawah peserta didik belum mampu untuk melakukan berbicara secara noninteraktif karena berbicara noninteraktif biasa di terapkan di kelas atas.

Kemampuan membaca peserta didik sebagai penerapan dua bahasa dalam pembelajaran sudah dilaksanakan melalui aktivitas peserta didik ketika membaca nyaring. Di kelas satu aktivitas yang dilakukan peserta didik yaitu mendeklamasikan sila ke-4 Pancasila di depan teman-teman kelas dengan suara yang nyaring dengan gerak tubuh sebagai alat bantu untuk membacakan kegiatan tersebut dilakukan secara bergantian. Di kelas dua peserta didik membaca nyaring dongeng fabel "kecerdikan menumbuhkan kebaikan", dalam pembelajaran ini guru menunjuk salah satu peserta didik untuk membacakan dongeng dengan suara yang nyaring dan teman-teman kelasnya mengikuti. Membaca nyaring bertujuan agar peserta didik terfokus dengan bacaan yang mereka baca. 
Kemampuan menulis peserta didik sebagai penerapan dua bahasa dalam pembelajaran sudah dilakukan melaui aktivitas riview atau meringkas dengan menggunakan strategi imajinatif. Di kelas satu peserta didik memahami isi bacaan "Hewan Peliharaan Beni", kemudian menyimpulkan isi bacaan dengan cara menuliskannya agar peserta didik tidak lupa dengan hasil kesimpulan yang telah mereka peroleh. Di kelas dua yaitu menuliskan cerita dogeng yang pernah disampaikan oleh guru dengan menggunakan konsep tulisan imajinatif sesuai dengan imajinasi mereka.

Mendengar adalah keterampilan memahami dengan cara meresapi suatu hal yang diterima, mendengar bunyi-bunyi bahasa tidak hanya didengar saja melainkan juga dengan dicerna. Kajain dalam artikel penelitian ini dari hasil observasi yang dilakukan ketika guru melakukan pembelajaran dalam RPP tema 7 "Benda, hewan, dan tumbuhan disekitarku" subtema 1 "Benda hidup dan tak hidup di sekitar kita" pembelajaran 4 kelas 1 bilingual. ${ }^{34}$ Peserta didik diajak guru untuk bernyanyi bersama kemudian guru memberi tugas peserta didik maju satu persatu untuk menyanyikan lagu "Topi saya bundar" peserta didik yang lain mendengarkan kegiatan ini dilakukan secara bergantian. ${ }^{35}$ Kegiatan menjelaskan perbedaan panjang pendek lagu ini bertujuan untuk mengetahui kemampuan mendengar dan ketelitian peserta didik saat pembelajaran berlangsung, karena dalam pembelajaran biasanya beberapa peserta didik bermain sendiri tidak memperhatikan pelajaran. ${ }^{36}$

Hasil observasi dilakukan ketika guru melakukan pembelajaran tematik tema 7 "Kebersamaan" subtema 1 "Kebersamaan di Rumah" pembelajaran 6 "Berkumpul Bersama Keluarga"37 sesuai dengan RPP yang dibuat oleh guru kelas II bilingual dengan melakukan aktifitas guru bercerita dongeng fabel "Sang Kancil dan Cicak Bandung". Pada kegiatan tersebut peserta didik memahami isi bacaan dongeng fabel "Sang Kancil dan Cicak Bandung" kemudian menceritakan kembali secara lisan yang diawali dengan menghayati, menceritakan kandungan pesan di dalam cerita, menjelaskan ide pokok dan gagasan pokok dalam dongeng fabel di hadapan guru dan teman-temannya. ${ }^{38}$

Kegiatan dalam pembelajaran, guru menjelaskan pengantar bacaan dongeng dengan menggunakan bahasa Jawa Krama Inggil :

\footnotetext{
${ }^{34}$ Dokumentasi, RPP, Wali Kelas 1, 20 April 2019.

${ }^{35}$ Dokumentasi, Jember, 20 April 2019.

${ }^{36}$ Observasi, Jember, 20 April 2019.

37 Dokumentasi, RPP, Wali Kelas 2, 13 April 2019.

38 Observasi, Jember, 13 April 2019.
} 
"Monggo di simak sedhanten bukunipun halaman 50, mangke bu guru crios dongeng hasil ceriose bu guru di rangkum dateng buku, sak sampune buguru crios ganti njenengan sedhanten maju setunggal - setunggal damel crios malih dongeng fabel "sang kancil dan cicak bandung" dhamel bahasa piambak - piambak" 39

Menurut Aida Rizaqul Khoiroh stategi bercerita dongeng ini memiliki maksud agar peserta didik mendengar dan cepat menangkap pesan, ide, dan gagasan yang terkandung dalam dongeng yang disampaikan oleh guru karena peserta didik kelas II bilingual ini mayoritas lebih senang mendengarkan dongeng dari pada membaca sendiri.

Berbicara adalah penyampaian maksud ide, pikiran, gagasan, atau isi hati seseorang kepada orang lain dengan menggunakan bahasa lisan sehingga maksud tersebut dapat di pahami oleh orang lain. Berbicara adalah kemampuan mengucapkan bunyi-bunyi artikulasi atau katakata untuk mengekspresikan, menyatakan serta menyampaikan pikiran, gagasan, dan perasaan. observasi yang dilakukan terkait dengan berbicara pada pembelajaran tematik kelas satu exellance tema 7 "Benda, hewan, dan tumbuhan disekitarku", subtema 2 "Hewan di sekitarku" pembelajaran $6,{ }^{40}$ pada kegiatan tersebut peserta didik melakukan kegiatan "bermain peran" setiap peserta didik dituntut berbicara karena dalam bermain peran mereka harus memerankan tokoh sekaligus menjiwai karakter tokoh yang mereka perankan. ${ }^{41}$

Hasil observasi pada kelas 2 bilingual yang dilakukan ketika guru melakukan pembelajaran dalam RPP tema 7 "Kebersamaan" subtema 1 "Kebersamaan di Rumah" pembelajaran 5 "Bermain Kucing dan Tikus di Air". ${ }^{42}$ Pembelajaran berupa diskusi dengan kelompok yang sudah dibentuk, tentang sikap terhadap teman yang memiliki kegiatan yang digemari berbeda. Kegiatan diawali dengan guru menjelaskan materi yang bersangkutan kemudian setelah menjelaskan guru membagi kelompok setiap kelompok terdiri dari 4 orang anak, setiap kelompok wajib mengumpulkan minimal dua kegiatan kebiasaan yang digemari teman yang berbeda, selanjutnya dengan hasil yang diperoleh mereka mendiskusikan hasilnya dengan guru, dalam diskusi setiap anak wajib menjelaskan hasil yang telah diperoleh. Setelah peserta didik mampu mendiskusikan tentang sikap terhadap teman yang memiliki kegiatan yang digemari berbeda, kemudian kegiatan dilanjutkan dengan mengerjakan lembar kerja

\footnotetext{
39 Observasi, Jember, 13 April 2019.

40 Dokumentasi, RPP, Wali Kelas 1, 22 April 2019.

${ }^{41}$ Observasi, Jember, 22 April 2019.

42 Dokumentasi, RPP, Wali Kelas 2, 16 April 2019.
} 
menuliskan kegemaran anggota keluarga di rumah dan mempresentasikan hasil diskusi di depan kelas. ${ }^{43}$

Penerapan kemampuan berbicara Krama Inggil peserta didik sudah sangat melekat pada diri mereka, aktivitas diskusi dilakukan secara berkelompok setiap diskusi peserta didik menggunakan Bahasa Krama Inggil, seluruh peserta didik terlihat sangat antusias dalam pembelajaran, hal ini terbukti ketika dilakukan wawancara dengan salah satu peserta didik yang menyatakan bahwa:

"Kulo remen sanget diskusi, sakbendinten kulo kaleh rencang kelas ndamel bahasa Jawa Krama Inggil supados terbiasa, bahasa seng sabendinten didhamel teng kehidupan sabendinten teng lingkungan ngriyo". ${ }^{4}$

Berdasarkan beberapa penjelasan tersebut dapat disimpulkan bahwa kemampuan berbicara peserta didik dengan menggunakan Bahasa Jawa Krama Inggil sudah melekat pada mereka, peserta didik sudah terbiasa menggunakan Bahasa Jawa Krama Inggil dalam kehidupan sehari-hari.

Membaca adalah suatu kegiatan memahami arti, yang terkandung di dalam tulisan, dan memahami pola-pola bahasa dari gambaran tulisan, membaca juga bisa dikatakan proses mengasosiasi huruf, penerjemahan, dan pemahaman makna bacaan.

Hasil wawancara tersebut sesuai dengan observasi di kelas satu excellance pembelajaran tematik tema 7 "Benda, hewan, dan tumbuhan disekitarku" subtema 1 "Benda hidup dan tak hidup di sekitar kita" pembelajaran $1 .{ }^{45}$ Aktivitas yang dilakukan peserta didik yaitu mendeklamasikan sila ke-4 Pancasila di depan teman-teman kelas dengan suara yang nyaring dengan gerak tubuh sebagai alat bantu untuk membacakan kegiatan tersebut dilakukan secara bergantian. ${ }^{46}$

Penerapan aktivitas membaca nyaring ditunjukkan oleh peserta didik di kelas 2 bilingual pada RPP tema 7 "Kebersamaan" subtema 1 "Kebersamaan di Rumah" pembelajaran 2 "Bermain Menjaring Ikan". Peserta didik melakukan kegiatan pembelajaran dengan menggunakan strategi membaca nyaring, peserta didik membaca nyaring dongeng fabel "kecerdikan menumbuhkan kebaikan", dalam pembelajaran ini guru menunjuk salah satu peserta didik untuk membacakan dongeng fabel "kecerdasan menumbuhkan kebaikan" dengan

\footnotetext{
${ }^{43}$ Observasi, Jember, 16 April 2019.

${ }^{44}$ Fahmi, Wawancara, Jember, 16 April 2019.

${ }^{45}$ Dokumentasi, RPP, Wali Kelas 1, 19 April 2019.

${ }^{46}$ Observasi, Jember, 19 April 2019.
} 
suara yang nyaring lalu peserta didik yang lain menirukan teman yang membaca didepan kelas. ${ }^{47}$

Berdasarkan beberapa pendapat tersebut dapat disimpulkan bahwa membaca merupakan salah satu kecerdasan verbal linguistik yang sangat berpengaruh karena kemampuan seseorang dalam menggunakan kata-kata secara lisan maupun tulisan secara efektif dalam membaca. Kemampuan membaca peserta didik sudah dilaksanakan melalui aktivitas peserta didik dalam pembelajaran tematik.

Menulis adalah keterampilan menuangkan, menggambarkan suatu bahasa melalui lambang atau simbol yang dipahami oleh seseorang sehingga orang lain dapat membaca dan memahami lambang-lambang atau simbol-simbol yang ditulis tersebut.

Hasil observasi yang dilakukan di kelas satu exellance ketika guru melakukan pembelajaran tematik tema 7 "Benda, hewan, dan tumbuhan disekitarku", subtema 2 "Hewan di sekitarku" pembelajaran 1, dengan melakukan kegiatan berlatih menuliskan aturan merawat hewan peliharaan yang diketahui. Pada kegiatan tersebut peserta didik memahami isi bacaan "Hewan Peliharaan Beni" 48 . kemudian menyimpulkan isi bacaan dengan cara menuliskannya agar peserta didik tidak lupa dengan hasil kesimpulan yang telah mereka peroleh. ${ }^{49}$

Pendapat tersebut dikuatkan dengan hasil observasi yang dilakukan ketika guru melakukan pembelajaran di kelas yaitu dengan pelajaran tematik tema 7 "Kebersamaan", subtema 2 "Kebersamaan di sekolah" Pembelajaran 6 "Lomba Kebersihan" yaitu menuliskan cerita dogeng yang pernah disampaikan oleh guru. ${ }^{50}$ Guru kemudian meminta peserta didik untuk mengumpulkan hasil dongeng yang telah mereka tulis dengan ringkas atau riview dengan konsep tulisan yang dibuat peserta didik adalah imajinatif sesuai dengan imajinasi mereka. ${ }^{51}$

Berdasarkan observasi tersebut aktivitas peserta didik yang berupa menulis ulang dongeng dengan menggunakan bahasa sendiri yang pernah disampaikan oleh guru kemampuan menulis peserta didik memudahkan mereka untuk mengingat kembali pelajaran yang sudah disampaikan, tulisan mereka dapat di buka kapan saja ketika mereka membutuhkan dan kegiatan menulis tersebut sangat membantu mempermudah belajar mereka. Kemampuan menulis ini menggunakan stategi imajinatif dimana peserta didik diminta merangkum dongeng

\footnotetext{
${ }^{47}$ Observasi, Jember, 13 April 2019.

${ }^{48}$ Dokumentasi, RPP, Wali Kelas 1, 21 April 2019.

${ }^{49}$ Dokumentasi, Jember, 21 April 2019.

50 Dokumentasi, RPP, Wali Kelas 2, 08 April 2019.

${ }^{51}$ Observasi, Jember 08, April 2019.
} 
atau meriview dengan konsep tulisan yang sesuai dengan imajinasi mereka tetapi tetap pada tema yang sudah ditentukan.

\section{KESIMPULAN}

Berdasarkan hasil penelitian yang dilakukan di Sekolah Dasar Nahdatul Ulama Kraton Kencong Jember tentang kecerdasan verbal linguistik pada penerapan dua bahasa dalam pembelajaran, maka dapat disimpulkan hal-hal sebagai berikut: (1) Kemampuan mendengar peserta didik secara interaktif di kelas satu dan dua dapat dikategorikan dalam kategori excellence: Peserta didik mengikuti pelajaran dengan baik, mulai dari kegiatan mendengar panjang pendek lagu, dan menceritakan kembali dongeng yang telah dipahami. (2) Kemampuan berbicara peserta didik secara interaktif di kelas satu dilakukan dengan aktivitas bermain peran dan di kelas dua dilakukan dengan kegiatan diskusi tentang sikap terhadap teman dan mempresentasikan hasil diskusi di depan kelas. (3) Kemampuan membaca peserta didik dilaksanakan dalam pembelajaran melalui membaca nyaring. (4) Kemampuan menulis peserta didik dilakukan melaui aktivitas review atau meringkas dengan menggunakan strategi imajinatif.

\section{DAFTAR PUSTAKA}

Al-Quran, 2010. Microsoft Word.

Chatib, Munif. 2012. Orang Tuanya Manusia Melejitkan Potensi dan Kecerdasan dengan Menghargai Fitrah Setiap Anak. Bandung: Kaifa.

Deni Kurniawan, 2014. Pembelajaran Terpadu Tematik (Teori, Praktik, dan Penilaian). Bandung : Alfabeta.

Durri Andriani dkk, 2011. Metode Penelitian, Jakarta: Universitas Terbuka.

Hanifah. 2014. Pemanfaatan media pop-up book berbasis tematik untuk meningkatkan kecerdasan verbal-linguistik anak usia 4-5 tahun (studi eksperimen di TK negeri pembina bulu temanggung). Belia: Early Childhood Education Papers. 3 (2). 46

Lexy J. Moleong, 2011. Metodologi Penelitian Kualitatif Edisi Revisi. Bandung: Remaja.

Lut Putu Artini \& Putu Kerti Nitiasih, 2014. Bilingualisme dan Pendidikan Bilingual, Yogyakarta: Graha Ilmu.

Lwin, May. 2008. Cara Mengembangkan Berbagai Komponen Kecerdasan. Jakarta: PT. Indeks Metthew B. Miles, etc, 2014. Qualitative Data Analysis A Methods Sourcebook. America: Arizona State University.

Mulyati. Yeti, dkk, 2009. Keterampilan Berbahasa Indonesia SD (Jakarta: Universitas Terbuka. Said. Alamsyah, dan Andi Budimanjaya. 2016. 95 Strategi Mengajar Multiple Intellegensi. Jakarta: Kencana.

Singgih, Gunarsa D. 2006. Dari Anak Sampai Usia Lanjut: Bunga Rampai Psikologi Perkembangan Jakarta: Gunung Mulia.

Suarca. 2016. Kecerdasan Majemuk Pada Anak. Jurnal Sari Pedriatri, 7 (2), 87 
Undang-Undang SISDIKNAS. 2018. (Sistem Pendidikan Nasional) \& PP No 32 Tahun 2013 Tentang Perubahan PP No. 19 Tahun 2015 Tentang Standar Pendidikan Nasional. Jakarta : Permata Press.

Utama, M.M.A, 2020, Student Motivation in Thematic Learning at Elementary Schools, Southeast Asean Journal Of Islamic Education. 3 (1), 1

Utama, M.M.A. 2018. Pengembangan Penilaian Authentik Bagi Guru MI .Indonesian Journal Of Islamic Teaching. 1 (1). 2

Yasa, Gede Sedana. 2014. Bimbingan Belajar. Yogyakarta: Graha Ilmu

Yaumi . 2015. Desain Strategi Pembelajaran untuk Mengembangkan Kecerdasan VerbalLinguistik Peserta Didik. Auladuna: Jurnal Pendidikan Dasar Islam, 2 (2), 186

Yaumi, Muhammad. 2018. Pembelajaran berbasis Multiple Intellegences (Jakarta: PT Dian Rakyat.

Yaumi. Muhammad, dan Nurdin Ibrahim, 2013. Pembelajaran Berbasis Kecerdasan Jamak (Multiple Intellegence) Mengidentifikasi dan Mengembangkan Multitalenta Anak (Jakarta: Prenamedia Group. 